\title{
Pengembangan Modul Pencemaran Lingkungan Berbasis Islam-Sains untuk Siswa Madrasah Aliyah/MA
}

\author{
Tisrin Maulina Dewi \\ Dosen Pend. Biologi Universitas Karimun, Tg. Balai Karimun, Kep. Riau Indonesia \\ Email: tisrinpascabio14@yahoo.com
}

\begin{abstract}
This study aims to determine: (1) The expedience degree of biology environmental pollution based Islamic-Science class X MA; (2) The responses of MA Biology teachers; and (3) The responses of students as to biology environmental pollution based Islamic-Science class X MA. This type of research is the development of research with product development model Borg and Gall, modified as needed. Data on quality of product development were collected by questionnaire. Data analyzed with descriptive quantitative and qualitative techniques. The results of this study showed that: (1) Validation of material expert is in very good criteria (88\%); (2) Validation of learning design expert is in very good criteria (86\%); (3) Assesment studies of biology teachers are in very helping criteria $(3,4) ;(4)$ individual testing are in good criteria $(80 \%)$; (5) A small test group are in very good criteria (88\%); Group confined field trials are in very good criteria $(90 \%)$, so it can concluded that module environmental pollution class X MA based Islamic-Science is fit for use as a supporting for learning environmental pollution at school.
\end{abstract}

Keywords: module development, environmental pollution, Islamic-Science

\section{PENDAHULUAN}

Secara harfiah madrasah berarti sekolah, karena secara teknis antara madrasah dan sekolah memiliki kesamaan yaitu sebagai tempat berlangsungnya proses belajar-mengajar secara formal. Pendidikan madrasah lahir sebagai upaya untuk memenuhi kebutuhan peserta didik sesuai dengan perkembangan ilmu pengetahuan dan teknologi.

Kemenag (2015) mengemukakan bahwa pendidikan madrasah menempatkan nilai-nilai Islam dan budaya luhur bangsa sebagai spirit dalam proses pengelolaan dan pembelajaran ditandai dengan intensitas dan kuantitas pembelajaran agama Islam, penciptaan suasana keberagaman Islam dalam lembaga pendidikan, penyediaan referensi dan sarana keagamaan serta keteladanan dalam pelaksanaan keagamaan Islam.

Terkait dengan eksistensi madrasah yang ada dalam Undang-Undang Sistem Pendidikan Nasional (UU Sisdiknas) No. 20 Tahun 2003, Nurkholis Setiawan selaku Direktur Pendidikan Madrasah Kemenag RI dalam Hidayatullah (2014) mengemukakan bahwa madrasah adalah sekolah umum berciri khas Islam, oleh karena itu diperlukan guru yang selalu menggali dan mengkaji sekaligus menerapkan teori-teori pengetahuan Islam untuk mengembangkan mutu madrasah serta guru harus menguasai mata pelajaran umum sesuai dengan bidangnya yang harus diimbangi dengan penguasaan ilmuilmu agama (tafaqquh fiddin).
Salah satu masalah penting yang sering dihadapi oleh guru adalah kurangnya kreativitas dan inovasi dalam menentukan dan menyusun bahan ajar yang tepat untuk kegiatan pembelajaran, padahal pengembangan profesionalisme guru perlu dilakukan melalui daya kreasinya untuk menciptakan pembelajaran yang lebih baik. Perolehan bahan ajar seharusnya tidak hanya didapatkan dari satu sumber saja karena dengan diperolehnya bahan ajar hanya dari satu sumber tidak akan dapat memaksimalkan hasil belajar. Adapun salah satu sumber belajar yang dapat disusun menjadi suatu bahan ajar adalah ayat-ayat Allah SWT yang berupa Al-Qur'an dan sabda Nabi Muhammad SAW berupa Hadits, keduanya merupakan sumber belajar yang di dalamnya bersifat pesan, kejadian, fakta dan peristiwa (Shihab, 2007).

Menurut Darmana, et al (2013), menghadirkan aspek spritual keagamaan melalui penanaman nilai-nilai agama tidak akan mengurangi bobot ilmiah dari sains, bahkan akan memastikan tercapainya pemahaman yang lebih komprehensif terhadap hakikat sains itu sendiri. Menghadirkan aspek spritual yang berbasis Islam-Sains ini salah satunya dengan menerapkan bahan ajar yang telah dikembangkan dari aspek tersebut, yang nantinya diharapkan dapat menjadi alternatif bagi guru dalam menyampaikan suatu materi pembelajaran sehingga proses belajar mengajar akan berjalan lebih optimal dan bervariasi. 
Dalam proses pembelajaran di kelas, guru membutuhkan banyak bahan ajar, salah satunya modul. Menurut Anwar (2010), modul pembelajaran adalah bahan ajar yang disusun secara sistematis dan menarik yang mencakup isi materi, metode, dan evaluasi yang dapat digunakan secara mandiri untuk mencapai kompetensi yang diharapkan. Dengan menggunakan modul, siswa dapat belajar secara mandiri tanpa atau dengan bimbingan guru, serta adanya kontrol terhadap hasil belajar melalui penggunaan standar kompetensi dalam setiap modul yang harus dicapai oleh siswa, dan mereka menjadi lebih bertanggung jawab atas segala tindakannya.

Hasil wawancara dengan salah satu guru biologi di Madrasah Aliyah Kabupaten Karimun Provinsi Kepulauan Riau bahwa dalam pembelajaran biologi masih menggunakan buku paket saja dan siswa juga kebanyakan malas untuk mencatat materi yang disampaikan oleh guru. Selain itu juga buku paket tersebut belum menunjukkan adanya kajian keislaman yang menghubungkan dengan kajian sains biologi. Selama ini sumber belajar yang digunakan siswa hanya berasal dari buku paket yang didapat dari memfotocopy buku pegangan milik guru dan siswa belum memiliki sumber belajar berupa modul yang berbasis Islam-Sains.

Terkait dengan masalah pencemaran lingkungan, sekolah menjadi salah satu sarana edukatif untuk menyampaikan tentang pentingnya menjaga kelestarian lingkungan. Materi pencemaran lingkungan merupakan salah satu materi yang termasuk dalam kompetensi inti dan kompetensi dasar yang harus dicapai dalam pembelajaran biologi kelas X SMA/MA. Muatan dan isyarat pendidikan terkait materi pencemaran lingkungan banyak terkandung di dalam Al-Qur'an dan Hadits, antara lain dalam Al-Qur' an Surat Ar-Rum (30) ayat 41 "Telah nampak kerusakan di darat dan di laut disebabkan karena perbuatan tangan manusia, supaya Allah merasakan kepada mereka sebahagian dari (akibat) perbuatan mereka, agar mereka kembali (ke jalan yang benar) [QS. Ar-Rum (30): 41].

Untuk lebih memahami tentang materi pencemaran lingkungan serta keterkaitannya dengan Al-Qur'an dan Hadits membutuhkan bahan ajar berupa modul pembelajaran yang baik yang memuat gambar-gambar tentang pencemaran lingkungan yang update dengan zaman sekarang. Selain gambar, terdapat langsung ayat-ayat Al-Qur'an dan Hadits yang berkaitan sehingga peserta didik bisa tahu manfaat dan mengagumi keesaan Sang Pencipta yaitu Allah SWT dan dapat menumbuhkan sikap peduli terhadap lingkungan, yang pada akhirnya akan diaplikasikan dalam kehidupannya sehari-hari karena akan berhubungan dengan lingkungan di sekitar masing-masing. Pada penelitian ini akan dikembangkan Modul Pencemaran Lingkungan Berbasis Islam-Sains dan mengetahui kualitasnya sebagai bahan ajar alternatif dalam pembelajaran biologi.

\section{METODE PENELITIAN}

Penelitian ini merupakan jenis penelitian Research and Development (R\&D) yang mengikuti prosedur penelitian pengembangan Borg dan Gall (1983). Produk penelitian yang dihasilkan berupa Modul Pencemaran Lingkungan Berbasis Islam-Sains untuk Siswa Kelas X Madrasah Aliyah/MA.

Desain penilaian produk dalam penelitian pengembangan ini adalah desain deskriptif kualitatif. Subjek penilaian yang menilai modul terdiri dari: (a) 2 orang ahli materi biologi, 3 orang ahli materi Islam-Sains, dan 2 orang ahli materi desain pembelajaran; (b) 4 guru biologi MA yaitu guru MAN Karimun fillial MAN Tanjungpinang, MAS Yaspika, dan MAS AlHuda Tanjungbatu ; dan (c) siswa MAN Karimun fillial MAN Tanjungpinang yang terdiri dari 3 siswa pada uji coba perorangan, 9 siswa pada uji coba kelompok kecil dan 27 siswa pada uji coba kelompok lapangan terbatas.

Jenis data yang diperoleh dalam penelitian berupa data kualitatif yang diperoleh dari hasil penilaian kelayakan modul. Instrumen pengumpulan data yang digunakan berupa lembar angket penilaian modul. Komponen penilaian meliputi komponen kelayakan isi, kelayakan penyajian, komponen Islam-Sains dan kelayakan desain pembelajaran.

Data kualitatif hasil penelitian diubah menjadi data kuantitatif dengan aturan pemberian skor sesuai yang dipaparkan Suparno (2011) untuk mempermudah menghitung skor rata-rata setiap komponen penilaian, selanjutnya nilai tiap komponen dimaknai dengan kalimat bersifat kualitatif (Sugiyono, 2015). 


\section{HASIL DAN PEMBAHASAN}

Hasil penelitian ini adalah produk berupa
Islam-Sains untuk Siswa Kelas X Madrasah Aliyah/MA (Gambar 1). Modul Pencemaran Lingkungan Berbasis

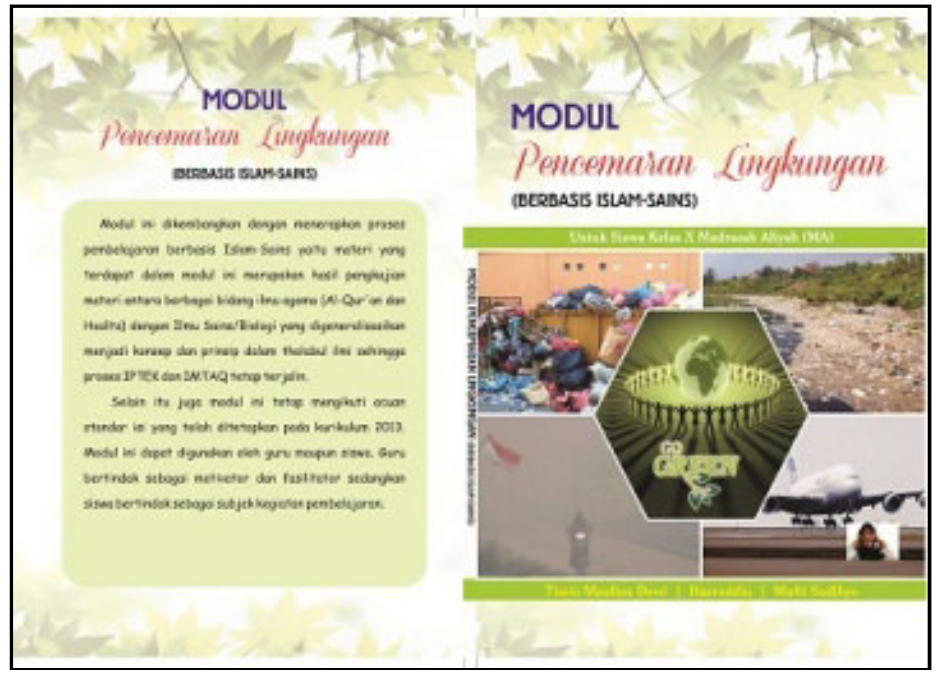

Gambar 1. Tampilan cover depan dan cover belakang Modul Pencemaran Lingkungan Berbasis Islam-Sains untuk Siswa Kelas X MA.

Para ahli terdiri dari tim ahli materi dan tim ahli desain. Para ahli materi memberikan penilaian terhadap produk modul pencemaran lingkungan berbasis Islam-Sains dengan kriteria sangat baik dan persentase sebesar $88 \%$ (Tabel 1). Sub komponen manfaat penyajian mendapat penilaian tertinggi dengan persentase sebesar $95 \%$ dengan kriteria sangat baik.

Tabel 1. Analisis Penilaian Berdasarkan Ahli Materi

\begin{tabular}{lcc}
\hline \multicolumn{1}{c}{ Sub Komponen Penilaian } & Persentase Rata-rata & Kriteria \\
\hline Kesesuaian Materi dengan KI dan KD & $88 \%$ & Sangat Baik \\
Keakuratan Materi & $85 \%$ & Sangat Baik \\
Materi Pendukung Pembelajaran & $91 \%$ & Sangat Baik \\
Teknik Penyajian & $85 \%$ & Sangat Baik \\
Penyajian Pembelajaran & $85 \%$ & Sangat Baik \\
Kelengkapan Penyajian & $89 \%$ & Sangat Baik \\
Kelengkapan Materi & $90 \%$ & Sangat Baik \\
Keakuratan Materi Integrasi Islam-Sains & $88 \%$ & Sangat Baik \\
Pengembangan Materi Berdasarkan Nilai-Nilai KeIslaman & $90 \%$ & Sangat Baik \\
Manfaat Penyajian & $95 \%$ & Sangat Baik \\
\hline \multicolumn{2}{c}{ Rata-rata } & $\mathbf{8 8 \%}$ \\
\hline
\end{tabular}

Para ahli materi memberikan masukan terhadap modul pada beberapa bagian seperti perbaiki kata/kalimat yang belum sesuai, pertajam konsep materi sains, penggunaan bahasa, ilustrasi gambar, pengkonsistenan penambahan khazanah Islam-Sains, serta penambahan dalil Al-Qur'an dan Hadits yang sesuai pada materi yang masih minim kajian keIslamannya.

Para ahli desain memberikan penilaian terhadap produk modul pencemaran lingkungan berbasis Islam-Sains dengan kriteria sangat baik dan persentase sebesar $86 \%$ (Tabel 2).

Tabel 2. Analisis Penilaian Berdasarkan Ahli Desain

\begin{tabular}{lll}
\hline Sub Komponen Penilaian & Persentase Rata-rata & Kriteria \\
\hline Ukuran Modul & $94 \%$ & Sangat Baik \\
Desain Kulit Modul & $83 \%$ & Sangat Baik \\
Desain Isi Modul & $80 \%$ & Baik \\
\hline Rata-rata & $\mathbf{8 6 \%}$ & Sangat Baik \\
\hline
\end{tabular}


Komponen penyajian modul ditentukan berdasarkan format penulisan sesuai dengan pendapat ahli dan berdasarkan acuan dari Depdiknas (2008) tentang komponenkomponen modul. Menurut Mulyasa (2006) modul pembelajaran dirancang secara sistematis untuk membantu siswa mencapai tujuan belajar. Oleh karena itu, perlu dirancang dan dikembangkan dengan mengikuti kaidah dan syarat-syaratnya.

Para ahli desain memberikan masukan terhadap modul pada beberapa bagian seperti penambahan gambar dalam setiap materi yang disajikan, penambahan kulit punggung dalam desain kulit modul, perbaiki warna, unsur tata letak dan desain gambar kulit modul.
Hasil respon tentang produk yang dikembangkan yang dilakukan oleh guru biologi berkategori sangat membantu dengan rata-rata penilaian sebesar 3,4 (Tabel 3). Indikator penyajian unsur Islam-Sains, penanaman nilai-nilai keIslaman, dan memotivasi siswa mendapat penilaian tertinggi dengan kriteria sangat membantu dan indikator keterpaduan materi dan memudahkan pemahaman siswa mendapat penilaian terendah tapi masih dalam kriteria membantu. Hal ini sesuai dengan hasil penelitian Gagne (1979) yang menyatakan bahwa buku ajar yang terbaik di dunia tidak akan memenuhi fungsi dan peranannya jika buku tersebut tidak disukai oleh seorang pengajar.

Tabel 3. Analisis Respon Guru Biologi

\begin{tabular}{llcc}
\hline No & Indikator & Skor Rata-rata & Kriteria \\
\hline 1 & Penyajian unsur Islam-Sains & 3,8 & Sangat membantu \\
2 & Penyajian kebenaran konsep ke-Islaman & 3,3 & Sangat membantu \\
3 & Kesesuaian dalil dengan konsep sains & 3,3 & Sangat membantu \\
4 & Penanaman nilai-nilai keIslaman. & 3,8 & Sangat membantu \\
5 & Keterpaduan materi & 3,0 & Membantu \\
6 & Penyajian ilustrasi & 3,3 & Sangat membantu \\
7 & Memotivasi siswa & 3,8 & Sangat membantu \\
8 & Ketepatan model informatif & 3,3 & Sangat membantu \\
9 & Ketepatan dengan nilai-nilai keIslaman & 3,5 & Sangat membantu \\
10 & Memudahkan pemahaman siswa & 3,0 & Membantu \\
11 & Memudahkan siswa belajar secara mandiri & 3,3 & Sangat membantu \\
\hline \multicolumn{2}{r}{ Rata-rata } & $\mathbf{3 , 4}$ & Sangat membantu
\end{tabular}

Siswa yang memberikan respon untuk modul ini yaitu pada uji coba perorangan, uji coba kelompok kecil dan uji coba kelompok lapangan terbatas (Tabel 4).

Tabel 4. Respon Siswa Kelas XI terhadap Modul yang dikembangkan

\begin{tabular}{lll}
\hline Indikator Penilaian dari & Persentase Rata-rata & Kriteria \\
\hline 3 Siswa & $80 \%$ & Baik \\
9 Siswa & $88 \%$ & Sangat Baik \\
27 Siswa & $90 \%$ & Sangat Baik \\
\hline
\end{tabular}

Data respon siswa terhadap modul yang dikembangkan mengalami peningkatan yaitu terjadi peningkatan sebesar $8 \%$ dari uji coba perorangan ke uji coba kelompok kecil dan peningkatan $2 \%$ dari uji coba kelompok kecil ke uji coba kelompok lapangan terbatas. Ini menunjukkan bahwa penyajian modul yang dikembangkan dinilai menarik perhatian siswa karena tampilan bahan ajar yang menyajikan gambar dan info-info terbaru yang sesuai dengan perkembangan biologi. Hal ini sesuai dengan penjelasan Direktorat Pendidikan (2004) bahwa sumber belajar dapat membantu memperkaya informasi dan mempelajari kompetensi tertentu.
Penilaian kelayakan modul ditentukan dari hasil penilaian modul pada tahap validasi dan uji coba kelayakannya. Berdasarkan penilaian yang dilakukan oleh para ahli materi, ahli desain, respon guru biologi dan respon dari siswa memperoleh penilaian dengan kriteria sangat baik. Menurut Prasetyo et al., (2011) menyatakan bahwa produk hasil pengembangan yang sudah dilakukan revisi berdasarkan masukan dan saran dari validator layak digunakan jika desain produk telah mendapat penilaian minimal berkriteria baik dari pihak validator. Modul pencemaran lingkungan berbasis Islam-Sains ini telah layak digunakan sebagai bahan ajar alternatif yang dapat 
mendukung proses pembelajaran biologi. Melalui materi dan kegiatan yang disajikan dalam modul ini diharapkan setelah siswa membaca dan mempelajari modul, mampu mendorong perubahan sikap siswa terhadap perubahan lingkungan serta mengimplementasikannya dalam kehidupan sehari-hari.

\section{SIMPULAN}

Simpulan dari penelitian ini adalah telah berhasil dikembangkan produk berupa modul pencemaran lingkungan berbasis Islam-Sains untuk siswa kels X Madrasah Aliyah/MA menggunakan model pengembangan Borg dan Gall. Modul ini mendapatkan penilaian yang sangat baik menurut tim ahli materi dan tim ahli desain dengan persentase rata-rata masingmasing $88 \%$ dan $86 \%$, respon dari guru biologi memiliki nilai 3,4 dengan kriteria sangat membantu serta respon dari siswa pada uji coba perorangan, uji coba kelompok kecil dan uji coba kelompok lapangan terbatas dengan masing-masing persentase $80 \%$ (baik), $88 \%$ (sangat baik) dan 90\% (sangat baik). Hasil ini mengindikasikan bahwa modul pencemaran lingkungan berbasis Islam-Sains yang dikembangkan layak digunakan dalam pembelajaran biologi sebagai salah satu sumber belajar. Mengingat penelitian ini hanya dilakukan sampai uji coba kelompok lapangan terbatas untuk mengetahui tanggapan dari para siswa, maka perlu adanya penelitian selanjutnya untuk menguji keefektifan modul pembelajaran yang dikembangkan, sehingga modul ini dapat lebih sempurna agar dapat dilakukan penyebaran produk.

\section{DAFTAR PUSTAKA}

Anwar, I. 2010. Pengembangan Bahan Ajar. Bahan Kuliah Online. Direktori UPI. Bandung.
Borg, W.R dan Gall, M.D. 1983. Educational Research: An Introduction (4 ed). Longman. New York \& London.

Darmana, Anna, Sofyan, Yayan. 2013. Pandangan Siswa terhadap Internalisasi Nilai Tauhid melalui Materi Termokimia. Prosiding Semirata FMIPA Universitas Lampung 2013: 37- 44.

Depag. 2005. Al-Qur'an dan Terjemahannya. Jumanatul Ali-Art. Bandung.

Depdiknas. 2008. Penulisan Modul. Ditjen PMPTK Depdiknas. Jakarta.

Direktorat Pendidikan. 2004. Pedoman Merancang Sumber Belajar. Jakarta: Balai Pustaka.

Gagne. 1979. Principles of Instructional.: Design. Holt Rinehart dan Winston. New York.

Hidayatullah. 2014. Ciri Madrasah Penjunjung Intelektualitas dan Moralitas. http://hidayatullah. or.id/read/berita-utama/2014/04/10/ciri-

madrasah-penjunjung- intelektualitas-danmoralitas. diakses Tanggal 05 September 2015.

Kemenag. 2015. Visi dan Misi Madrasah. http://madrasah.kemenag.go.id/ tentang_ madrasah/ afe4c9a4b6c142eeaf216331a138b3d3/ visi_misi.html. diakses tanggal 05 September 2015.

Mulyasa. 2006. Kurikulum yang disempurnakan Pengembangan Standar Kompetensi dan Kompetensi Dasar. PT. Remaja Rosdakarya. Bandung.

Prasetyo., Z.Kun. 2011. Pengembangan Perangkat Pembelajaran Sains Terpadu untuk Meningkatkan Kognitif, Keterampilan Proses, Kreativitas serta Menerapkan Konsep Ilmiah Peserta Didik SMP. Laporan Penelitian. Yogyakarta. Universitas Negeri Yogyakarta. http://www.google.co.id/ url?sa=t\&source=web\&rct=j\&url=http://staff.un y.ac.id. diakses tanggal 20 Januari 2016

Shihab, Q. 2007. Wawasan Al-Qur'an: Tafsir Tematik Atas Pelbagai Persoalan Umat. PT. Mizan Pustaka. Bandung.

Sugiyono. 2015. Metode Penelitian Pendidikan Pendekatan Kuantitatis, Kualitatif dan $R \& D$. Alfabeta. Bandung.

Suparno. 2011. Pengembangan Bahan Ajar Mata Diklat Adaptif Berbasis Web Based Learning pada Sekolah Menengah Kejuruan Jurusan Teknik Bangunan. Jurnal Teknologi dan Kejuruan 34(1): 61-70. 